\title{
MEMBANGUN PRIVILEGES PADA JARINGAN KOMPUTER SMA NEGERI 2 BOYOLALI BERBASIS ACTIVE DIRECTORY DENGAN WINDOWS SERVER 2008 ENTERPRISE
}

\author{
Fite Kurniawan, Fajar Suryawan, Umi Fadlilah \\ Jurusan Teknik Elektro Fakultas Teknik Universitas Muhammadiyah Surakarta \\ Jl. A. Yani Tromol Pos 1 Pabelan Kartasura Surakarta \\ E-mail: fitekurniawan@gmail.com
}

\begin{abstract}
ABSTRAKSI
SMA Negeri 2 Boyolali saat ini telah memiliki perangkar keras (hardware) yang telah terhubung dengan jaringan internet dan komputer. Kondisi jaringan internet dan komputer yang telah terinstalasi pada SMA Negeri 2 Boyolali belum terinstalnya sistem operasi Windows Server 2008 Enterprise dan Active Directory pada komputer server, tentunya menyulitkan pekerjaan administrator memanajemen user dan group, membagi hak akses (privileges), karena harus melakukan setting satu per satu pada komputer client. Selain itu, siswa harus mengantri untuk meminta materi pelajaran dari guru menggunakan flash drive, sehingga keamanan file pun kurang terjamin serta rawan akan virus. Begitu juga dengan staff karyawan.

Penelitian ini menggunakan metode studi literatur, eksperimen, interview, observasi, dan sampling. Tujuan dari penelitian ini adalah untuk membangun privileges pada jaringan komputer SMA Negeri 2 Boyolali berbasis Active Directory, instalasi dan konfigurasi privileges komputer server dengan menggunakan Windows Server 2008 Enterprise, melakukan manajemen user dan group bagi siswa, guru, dan staff karyawan dengan Active Directory, membuat user dan group, mengatur pemberian hak akses (privileges) terhadap masing-masing user dan group.

Penelitian ini, maka jaringan komputer yang ada di SMA Negeri 2 Boyolali telah terbangun privileges berbasis Active Directory pada Windows Server 2008 Enterprise yang memudahkan pekerjaan administrator memanajemen user dan group, pemberian hak akses (privileges) setiap user dan group, tidak harus melakukan setting satu per satu pada komputer client. Selain itu, siswa tidak perlu mengantri untuk meminta materi pelajaran dari guru menggunakan flash drive, cukup mengakses komputer client di laboratorium komputer yang telah terhubung jaringan dan login ke server Windows Server 2008 Enterprise Active Directory kemudian masuk ke folder sesuai dengan privileges yang ditentukan oleh administrator, sehingga keamanan file pun terjamin dari virus. Begitu juga dengan staff karyawan.
\end{abstract}

Kata Kunci: Active Directory, Jaringan Komputer, Privileges, Windows Server 2008 Enterprise

\section{PENDAHULUAN}

Teknologi informasi dan telekomunikasi pada saat ini telah terbukti sebagai sarana komunikasi dan sumber informasi yang sangat handal.Seiring dengan kemajuan dan perkembangan teknologi yang semakin canggih dengan perkembangannya semakin cepat, teknologi informasi yang berkembang pesat pada saat ini salah satunya dalam bidang jaringan, khususnya jaringan komputer.

Sekarang ini, manfaat dari jaringan komputer sudah banyak dirasakan dan digunakan.Apalagi dalam dunia komunikasi yang serba cepat dan efisien saat ini, jaringan komputer berperan vital dalam kegiatan pendistribusian komunikasi data dan informasi yang cepat dan efisien.Semua komponen yang tergabung dalam suatu jaringan haruslah saling mendukung untuk menghasilkan satu sistem yang kokoh dan handal untuk melayani setiap pengguna.Hampir semua perkantoran, instansi (badan usaha), lembaga pendidikan, sekolah hingga universitas sudah menggunakan layanan jaringan komputer. Tetapi, masih banyak tempat tersebut yang belum membangun privileges berbasis Active Directory yang terkomputerisasi. Seperti yang penulis temukan pada SMA Negeri 2 Boyolali.

Melihat kenyataan itu, maka penulis mencoba memberikan solusi yang tepat untuk 
kelancaran keadministrasian sekolah secara optimal dengan membangun privileges berbasis Active Directory pada jaringan komputer telah ada dengan perangkat lunak sistem operasi Windows Server 2008 Enterprise yang nantinya akan diinstal pada komputer server. Dengan adanya privileges berbasis Active Directory, memudahkan pekerjaan administrator memanajemen user dan group, pemberian hak akses (privileges) setiap user dan group, tidak harus melakukan setting satu per satu pada komputer client. Selain itu, siswa tidak perlu mengantri untuk meminta materi pelajaran dari guru menggunakan flash drive, cukup mengakses komputer client di laboratorium komputer yang telah terhubung jaringan dan login ke serverWindows Server 2008 Enterprise Active Directory kemudian masuk ke folder sesuai dengan privileges yang ditentukan oleh administrator, sehingga keamanan file pun terjamin dari virus. Begitu juga dengan staff karyawan.

Penelitian ini dikembangkan dari beberapa referensi yang telah didapat yang berhubungan dengan objek permasalahan. Penelitian tersebut diantaranya :

Perancangan dan Implementasi Active Directory pada Jaringan Komputer berbasis Windows Server 2003". Secara garis besar penelitiannya, merancang dan mengimplementasikan Active Directory pada jaringan komputer Toshiba-TSSI Tosplant JO berbasis Microsoft Windows Server 2003, sehingga memudahkan pekerjaan administrator lebih mudah dalam menerapkan suatu user atau group dan pekerjaan karyawan menjadi lebih efektif dan efisien (Joko Sulistyo, 2006).

Membangun File Server pada Laboratorium Komputer SMA Muhammadiyah 2 Surakarta dengan Windows Server 2008 Enterprise". Tujuan penelitian tersebut untuk mendesain jaringan laboratorium di sekolah, instalasi dan konfigurasi file server dengan menggunakan Windows Server 2008 Enterprise, melakukan manajemen user bagi siswa dan guru dengan menggunakan Active Directory, membuat user dan group, mengatur pemberian hak akses, pengaturan quota, pembuatan printer sharing.
Hasil penelitian tersebut bahwa jaringan laboratorium SMA sekarang telah berbasis server-client yang memudahkan murid ataupun guru dalam melakukan proses pemberian dan pengumpulan tugas (Adin Tri Wicaksono, 2008).

Akses dan privileges adalah dua hal yang sangat dibutuhkan dalam membangun hak akses mulai dengan database, menggunakan fasilitas manajemen membership dan Active Directory. (http://www.zonenetworking.co.cc) Active Directory adalah database terdistribusi dan layanan direktori yang direplikasi diantara semua domain controller pada jaringan.Database Active Directory menyimpan semua informasi tentang objek jaringan termasuk domain, komputer, pengguna, dan lain-lain. (Joko Sulistyo : 2006)

Active Directory sebenarnya implementasi dari protokol Lightweight Directory Access Protocol (LDAP).LDAP adalah salah satu protokol direktori yang sampai saat ini masih bertahan dan populer digunakan di kelas menengah dan enterprise. (http ://blog.ub.ac.id)

LDAP adalah TCP/IP berbasis protokol internet yang digunakan oleh program e-mail dan beberapa aplikasi lain untuk mencari dan mengambil informasi sebuah direktori disimpan pada sebuah server.

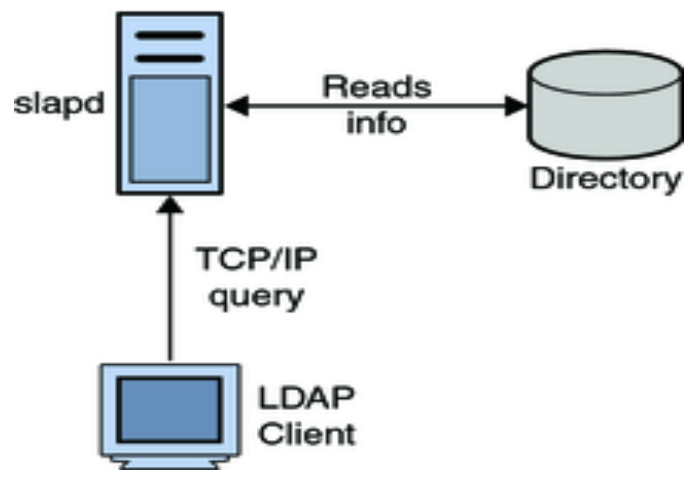

Gambar 1. LDAP

Beberapa produk yang tersedia pada LDAP dan dapat digunakan antara lain :

1. Microsoft Active Directory.

2. Fedora Active Directory. 
3. Mandriva Active Directory.

4. SUSE Linux Enterprise.

5. Open LDAP.

6. Turnkey Linux LDAP. (http://computer-muter.blogspot.com)

\section{METODE PENELITIAN}

Penggambaran topologi jaringan, penginstalan Windows Server 2008 Enterprise, penginstalan Active Directory dan pembangunan privileges berbasis Active Directory.

2.1. Peralatan Utama dan Pendukung

\subsubsection{Peralatan Utama}

Pada Penelitian ini, membutuhkan perangkat keras (hardware) dan perangkat lunak (software).

1. Perangkat Keras

Perangkat keras yang dibutuhkan untuk penelitian ini pada jaringan komputer SMA Negeri 2 Boyolali, yaitu :

1.1. Komputer Server dengan spesifikasi :

a. Processor Pentium $\AA$ Dual Core E5700 3 $\mathrm{GHz}$.

b. Memory (Random Access Memory) 2048 MB.

c. Harddisk Drive SATA 160 GB.

d. StandartKeyboard, Mouse, Speaker.

e. Floppy Disk Drive 3,5 Inchi dan CD-RW Samsung Optical Drive.

f. Operasi Sistem Windows Server 2008 Enterprise 32-bit.

g. Monitor Samsung LED 15,6".

1.2. Komputer client dengan spesifikasi sebagai berikut : a. Processor Pentium ${ }^{\circledR}$ Dual Core E5700 2,6 $\mathrm{GHz}$

b. Memory (Random Access Memory) 1024 MB.

c. Harddisk Drive SATA 80 GB.

d. Standart Keyboard, Mouse.

e. Floppy Disk Drive 3,5 Inchi dan CD-RW Samsung Optical Drive.

f. Operasi Sistem Windows 7 Ultimate 32-bit.

g. Monitor Acer LED 15,6”.

switch, NIC, konektor RJ-45, kabel UTP, dan lain sebagainya yang berhubungan dengan koneksi jaringan komputer.

2. Perangkat Lunak

a. Sistem operasi untuk komputer server menggunakan Windows Server 2008 Enterprise.

b. Sistem operasi untuk komputer client menggunakan Windows 7 Ultimate 32-bit.

\subsubsection{Peralatan Pendukung}

Peralatan pendukung yang dibutuhkan dalam penelitian ini adalah Printer Canon IP2770 Pixma dan Laptop Toshiba L510 Black Edition dengan spesifikasi sebagai berikut :

a.Processor®Dual-CoreT4400@2.20 GHz.

b. RAM 2 GB Visipro SODIMM DDR3.

c. Harddisk Toshiba 250 GB ATA.

d. Sistem Operasi Windows 7 Alchemist Ultimate 32-bit.

e. DVD RW Optic Driver.

f. LCD Monitor 16"

g. VGA Intel On Board 829 MB.

Metode Penelitian yang digunakan adalah studi literatur, eksperimen, interview, observasi, dan sampling. 
Pada Gambar 2, skema privileges berbasis Active Directory pada user siswa yang terdiri dari 10 user siswa. Gambar 3, skema privileges berbasis Active Directory pada user guru yang terdiri dari 18 user guru. Dan Gambar 4, adalah skema privileges berbasis Active Directory pada user staff. Terdiri dari 8 user staff.
Secara keseluruhan skenario pada gambar 2, 3, dan gambar 4 dapat dijelaskan bahwa Pada sisi komputer server yang telah terinstal Windows Server 2008 Enterprise dan Active Directory, ketika Administrator menjalankan Active Directory Users and Computers maka akan terlihat pada bagian Domain.

\subsection{Skenario Membangun Privileges berbasis Active Directory}

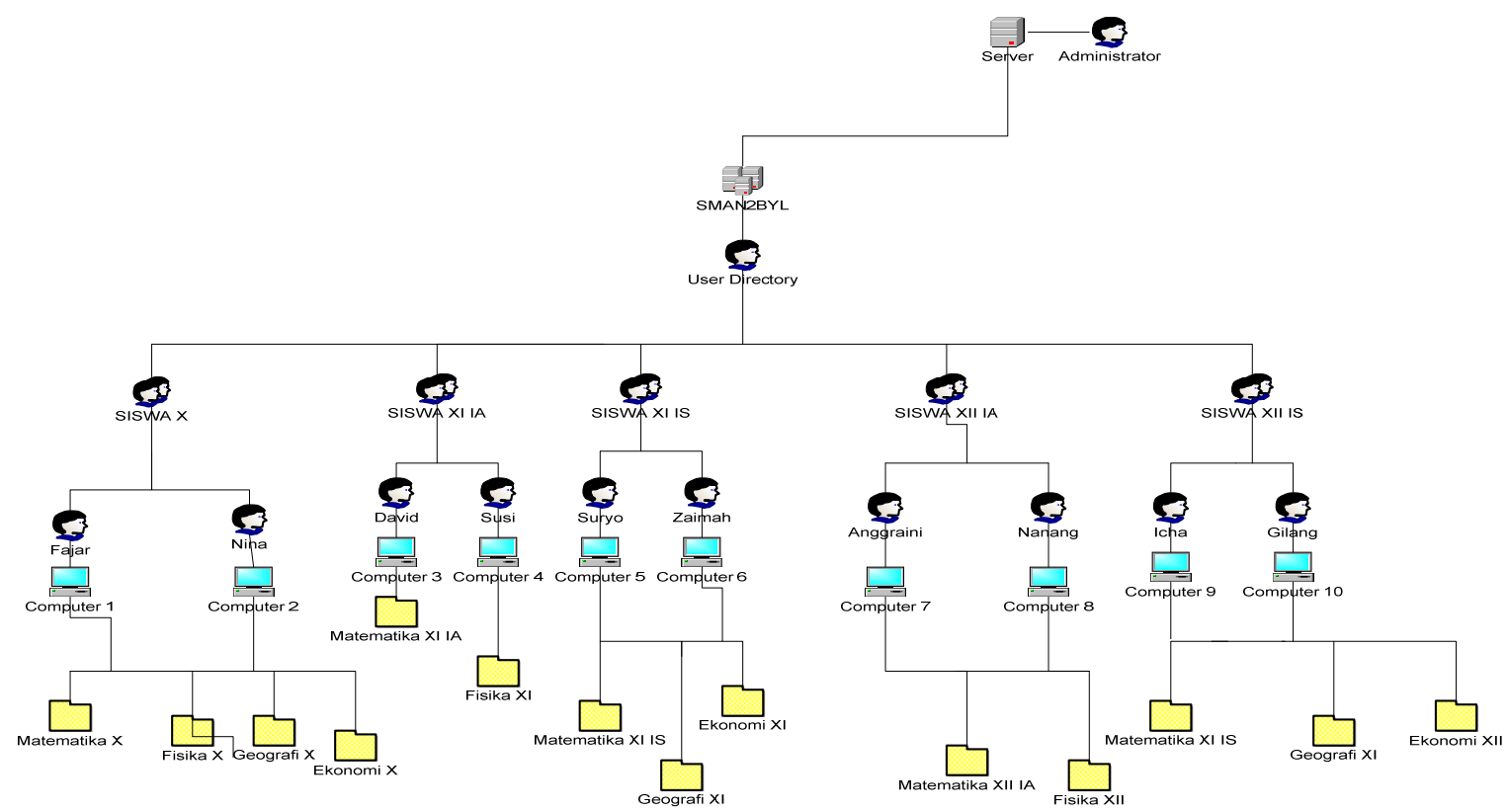

Gambar 2.Privileges berbasis Active Directory pada User Siswa 


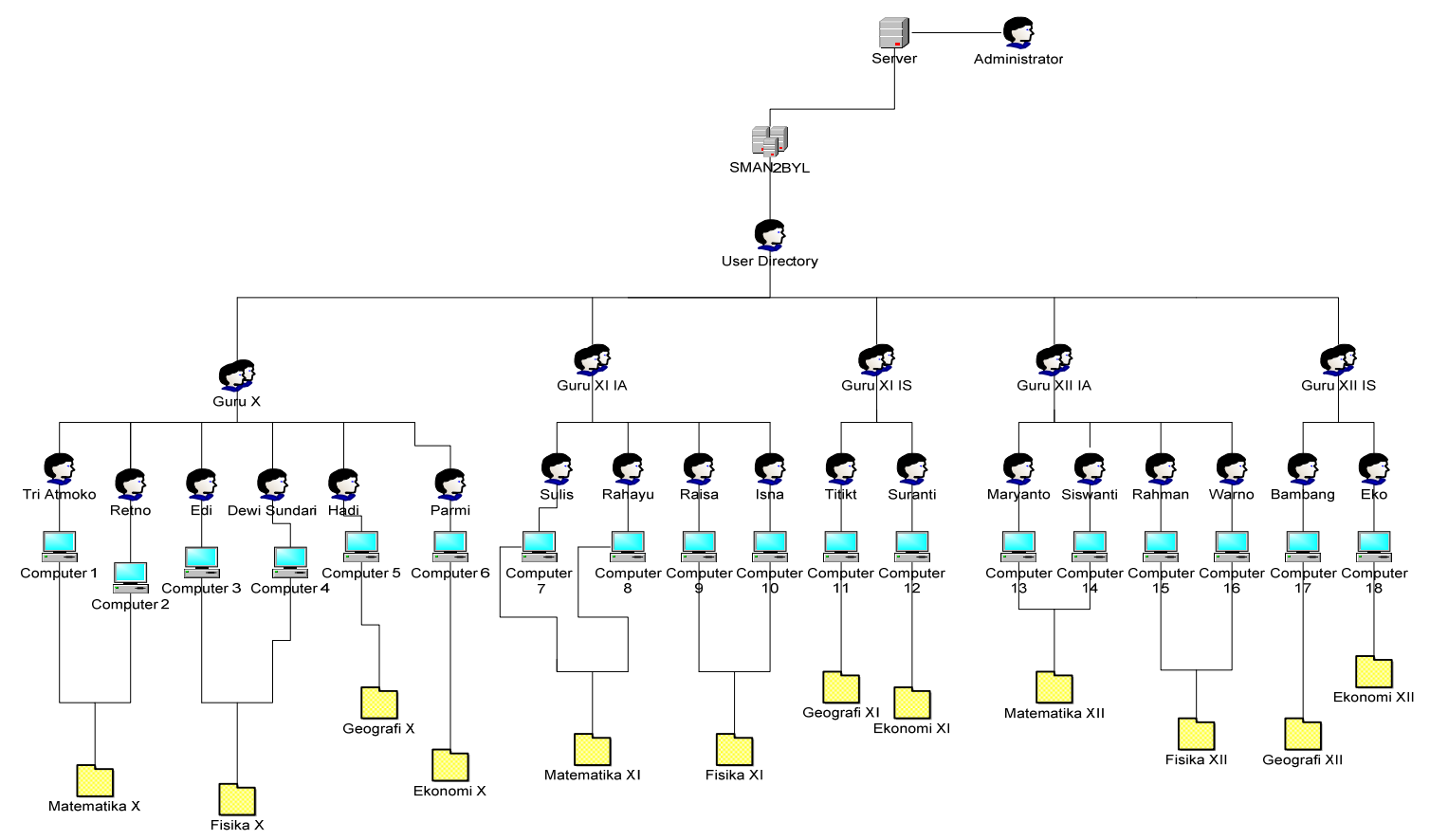

Gambar 3.Privileges berbasis Active Directory pada User Guru

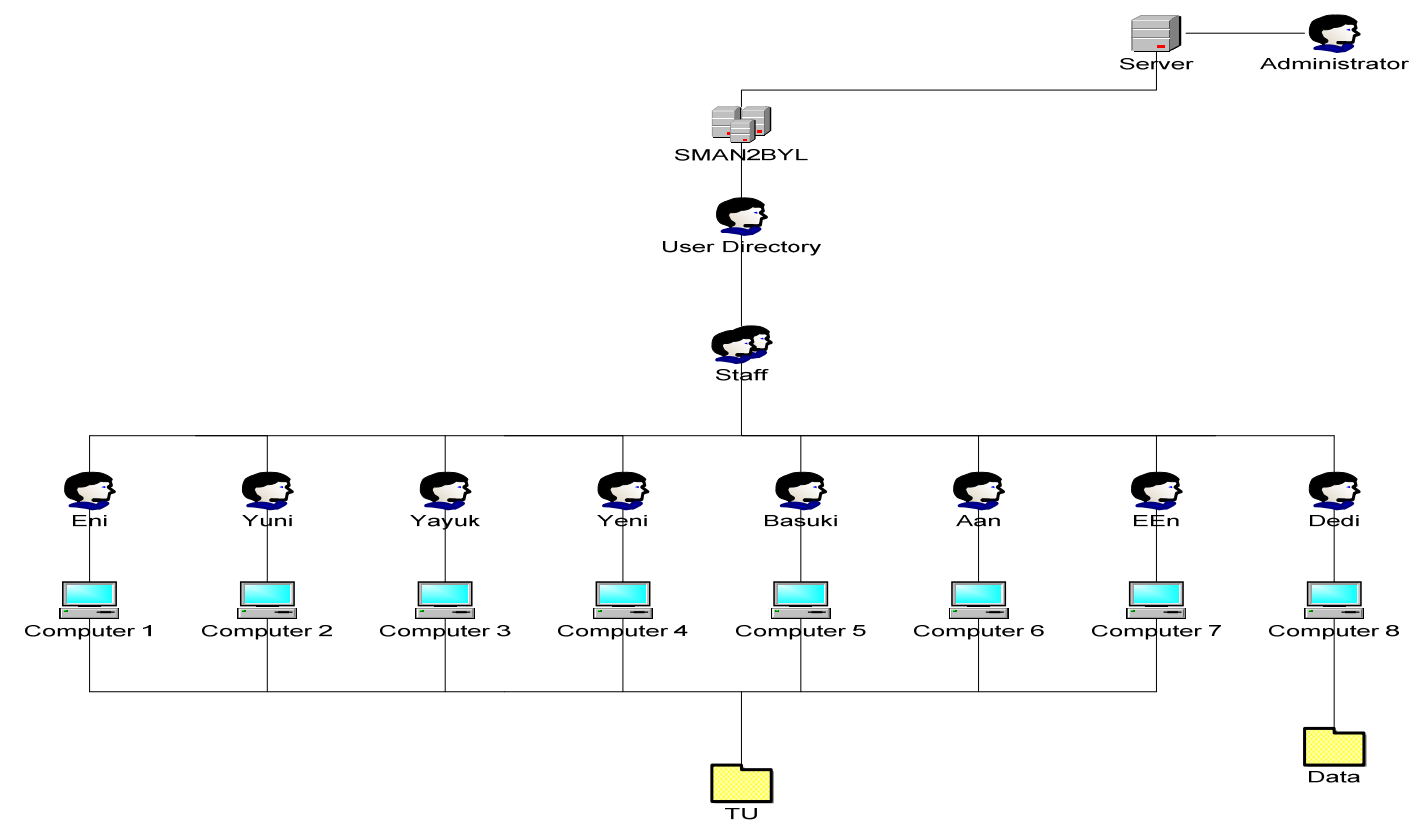

Gambar 4.Privileges berbasis Active Directory pada User Staff

Di dalam Domain terdapat salah satu user directory yang berfungsi untuk menyimpan group, pengguna, dan lain-lain. Setiap group memiliki beberapa user yang menggunakan komputer client masing-masing telah ditentukan hak akses (privileges) folder oleh administrator. Jadi, masing-masing user tidak dapat membuka data user lainnya.Apabila, ada salah satu user yang ingin masuk ke folder sharing yang bukan haknya, maka pengaksesan langsung ditolak.

3. HASIL PENELITIAN \& ANALISA 


\subsection{Hasil Penelitian}

Hasil penelitian ini pada dasarnya dibagi menjadi dua bagian, yaitu hasil studi lapangan mengenai perangkat keras (komputer) yang sudah dimiliki SMA Negeri 2 Boyolali telah terhubung dengan jaringan, topologi jaringan, kecepatan akses upload-download, dan hasil instalasi dan konfigurasi Active Directory berbasis Windows Server 2008.

Windows Server 2008 termasuk salah satu operasi sistem untuk server dan pengelolaan jaringan.Operasi sistem ini diinstal dan dikonfigurasikan pada komputer server.Setelah selesai menginstal Windows Server 2008 Enterprise pada komputer server, barulah menginstal dan mengkonfigurasi Active Directory.Konfigurasi Active Directory yang digunakan pada Active Directory adalah Active Directory Users and Computers.

\subsection{Analisa}

\subsubsection{Analisa Hardware}

Beberapa hardware yang digunakan untuk membangun Active Directory antara lain :

a. Komputer server Pentium ${ }^{\circledR}$ Dual Core E5700 3 GHz, RAM 2048 MB, Harddisk SATA 160 GB, Standart Keyboard, Mouse, Speaker, Floppy Disk Drive 3,5 Inchi dan CD-RW Samsung Optical Drive, Monitor LED Samsung 15,6".

b. Operasi sistem yang digunakan pada komputer server adalah Windows Server 2008 Enterprise.

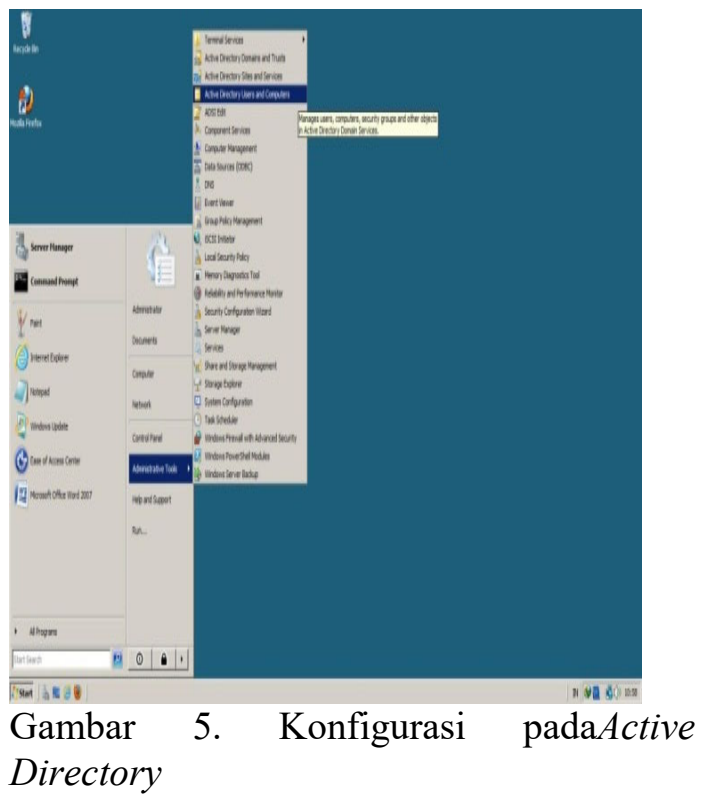

1. Server

Server digunakan agar dapat mengetahui manfaat adanya komputer server yang telah ada pada jaringan komputer SMA Negeri 2 Boyolali. Gambaran pada server:

a. Server dapat digunakan manajemen user dan group

Pembuatan user dan group, hanya para siswa, guru, dan staff karyawan yang diatur manajemen usernya, sehingga antara siswa satu dengan yang lain, guru satu dengan yang lain, staff karyawan yang satu dengan lain tidak membisa membuka folder yang bukan haknya. Karena staff IT bertindak sebagai administrator sekaligus pemakai komputer server. Maka, staff IT yang mengatur apa saja folder yang dapat diakses oleh para siswa, guru, dan staff karyawan. Berikut hak akses yang diberikan pada user.

\section{User Siswa}

a. Siswa dapat melakukan penyimpanan, menghapus, dan mengubah file yang berada pada folder siswa masingmasing.

b. Siswa hanya dapat melihat isi folder data umum dan hanya bisa mengkopi file yang ada di dalamnya. 
c. Siswa tidak dapat membuka folder atau file siswa lainnya.

\section{User Guru}

a. Guru dapat melakukan penyimpanan, menghapus, dan mengubah file yang berada pada folder guru masing-masing.

b. Guruhanya dapat melihat isi folder data umum dan hanya bisa mengkopi file yang ada di dalamnya.

c. Gurutidak dapat membuka folder atau file guru lainnya.

\section{User Staff Karyawan}

a. Staff karyawan dapat melakukan penyimpanan, menghapus, dan mengubah file yang berada pada folder staff karyawan masing-masing

b. Staff karyawan hanya dapat melihat isi folder data umum dan hanya bisa mengkopi file yang ada didalamnya.

c. Staff karyawan tidak dapat membuka folder atau file staff karyawan lainnya.

\section{Staff IT (Administrator)}

a. Staff IT dapat membuat user dan group.

b. Staff IT dapat mengganti dan menghapus hak akses yang telah diberikan.

c. Staff IT dapat melihat, menghapus, dan merubah apa yang terdapat pada folder siswa, guru, staff karyawan.

d. Staff IT dapat mengatur jaringan yang telah ada.

b. Server dapat dijadikan sebagai pusat penyimpanan data yang aman.

Sebagai pusat penyimpanan data yang aman harus memiliki keamanan dari serangan virus-virus yang dapat merusak sistem atau data-data yang telah ada.Antivirus adalah salah satu keamanan (security) yang sangat penting, sehingga virus tidak mudah masuk ke komputer server.Komputer server menggunakan satu antivirus free yaitu Avira yang cukup ampuh untuk membasmi virusvirus yang masuk ke komputer server.Dengan pusat data yang aman, maka data-data yang tersimpan secara terpusat di komputer server terjamin keamanannya.

\section{Client}

Client digunakan agar mengetahui manfaat komputer client yang ada pada jaringan komputer tersebut. Berikut gambaran komputer client

a. Komputer client dapat digunakan untuk mengakses data yang terdapat pada komputer server sesuai hak akses yang diberikan administrator.

b. Komputer client dapat digunakan user untuk menyimpan file user di komputer server sesuai batasan alokasi memori pengguna (quota user) yang ditentukan oleh administrator.

\subsubsection{Analisa Software}

Pada Windows Server 2008, file system yang digunakan adalah NTFS. Jenis file system ini lebih cepat, aman dan mendukung ukuran harddisk yang lebih besar dibandingkan FAT dan FAT32. Jenis file system NTFS ini mendukung penggunaan Active Directory yang akan digunakan pada pada penelitian ini. Windows Server 2008 yang diinstal pada penelitian ini adalah versi Enterprise Edition

Setelah selesai menginstal Microsoft Windows Server 2008 Enterprise selesai tanpa ada hambatan dan kesalahan, langkah selanjutnya adalah instalasi Active Directory.Pada versi Windows Server sebelumnya, mungkin sangat familiar dengan mengetik "DCPROMO"tanpa tanda kutip pada Run.Untuk Install Active Directory, sebenarnya cukup ketik DCPROMO pada Run. Akan tetapi, Windows Server 2008 menyediakan feature Roles. Dimana, ada 
langkah tambahan yang perlu diambil sebelum menjalankan perintah DCPROMO untuk menjadikan sebuah server menjadi Domain Controller dan menginstal Active Directory pada server tersebut.Langkah ini adalah instalasi Active Directory Domain Services (ADDS) role yang ada pada Windows Server 2008.

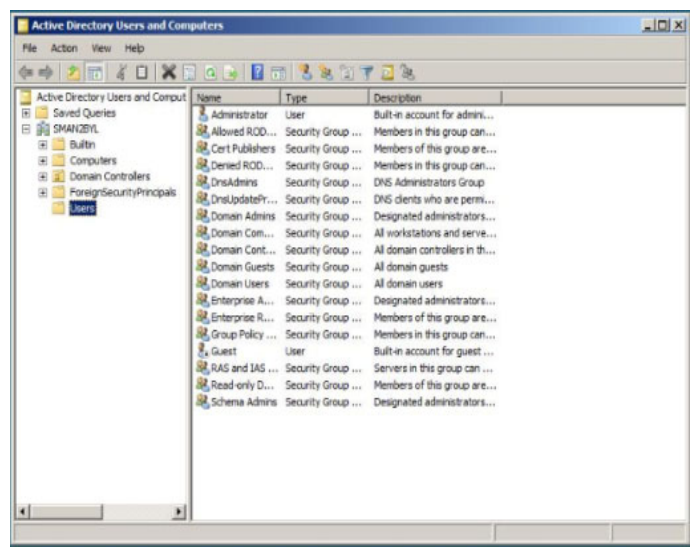

Gambar 7.Active Directory User and Computers

\subsubsection{Analisa Membangun Privileges berbasis Active Directory}

\subsubsection{Folder Sharing}

Folder Sharing adalah suatu folder tertentu pada suatu komputer yang sengaja dibuat untuk diakses bersama-sama di dalam jaringan lokal (LAN).

\subsubsection{Map Network Drive}

Map Network Drive adalah sebuah fasilitas windows untuk mapping sebuah folder yang dishare ke jaringan menjadi sebuah drive pada Personal Computer.

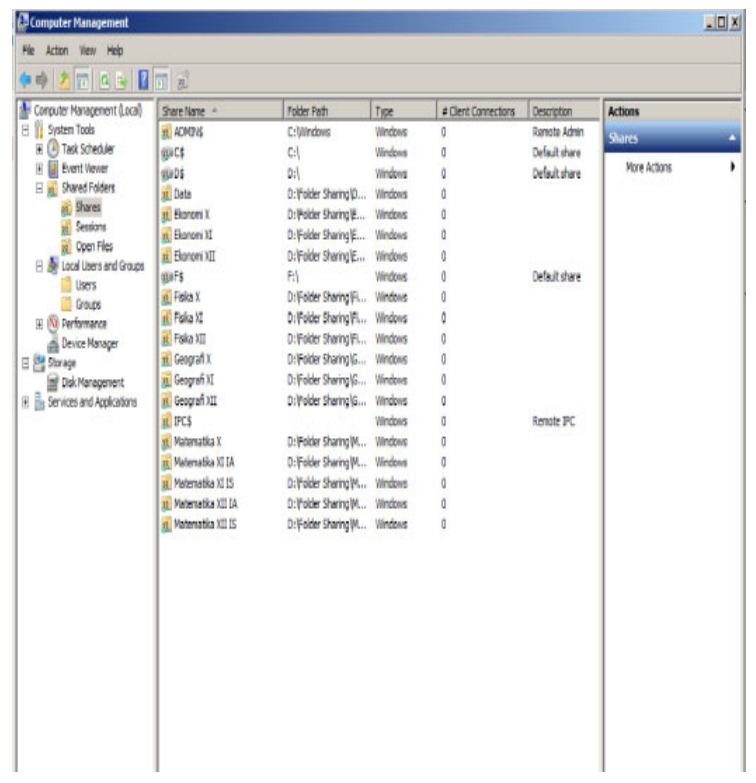

Gambar 8. Hasil Folder Sharing

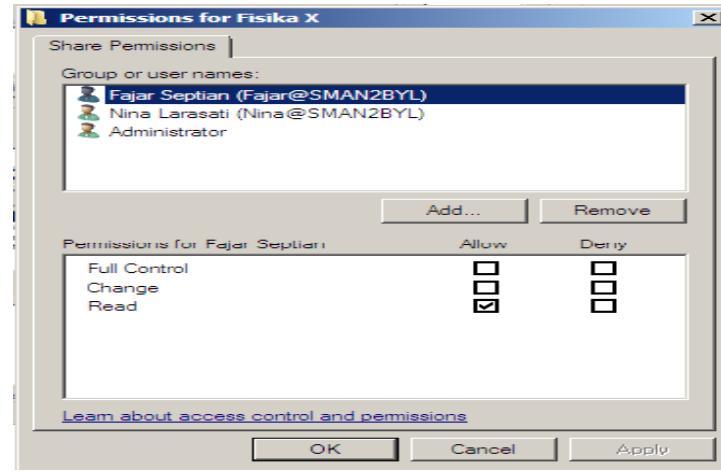

Gambar 10.Privileges

Pada Gambar 9, hasil pemetaan drive. Pengaksesan folderuser dan group akan lebih mudah menggunakan pemetaan folder pada logical drive. Sedangkan pada Gambar 10, privileges. Privileges digunakan untuk mengatur izin penggunaan folder serta file 
yang ada di dalamnya dapat dilakukan dengan cara membuka Windows Explorer.

\subsection{Pengujian}

Pengujian software yang digunakan adalah sistem operasi Windows Server 2008 Enterprise untuk komputer server.Sedangkan komputer client menggunakan sistem operasi Windows 7 Ultimate 32-bit. Berikut ini adalah diagram alur pengujian privileges berbasis Active Directory.

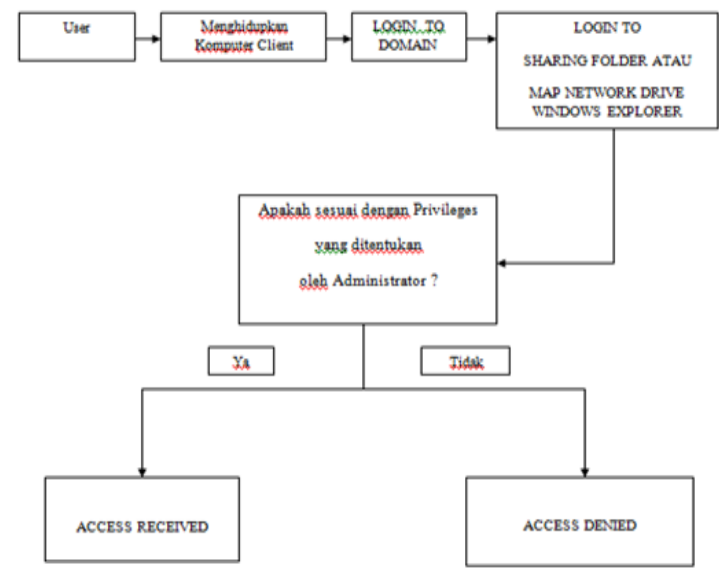

Gambar 11. Diagram Alur Pengujian

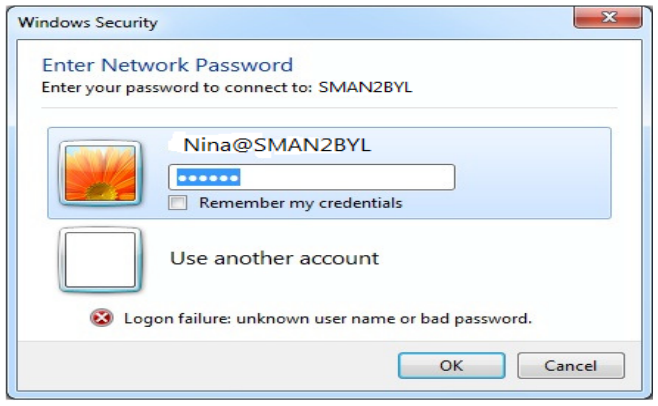

Gambar 12.Login ke Folder Sendiri

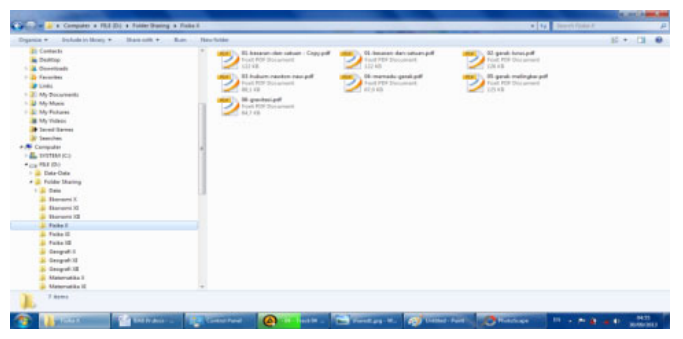

Gambar 13. Isi Folder User setelah Login

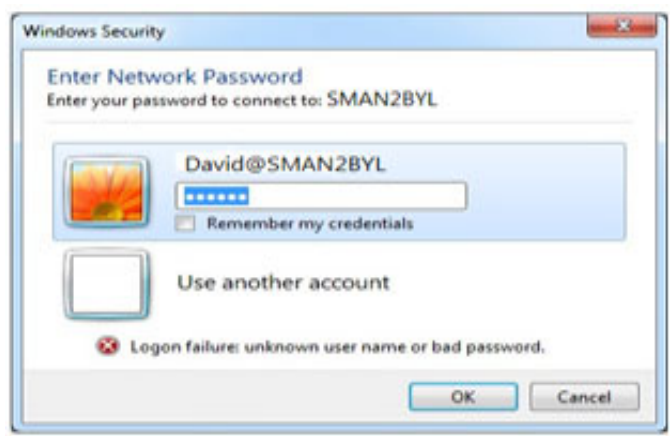

Gambar 14.Login ke Folder yang Bukan Haknya

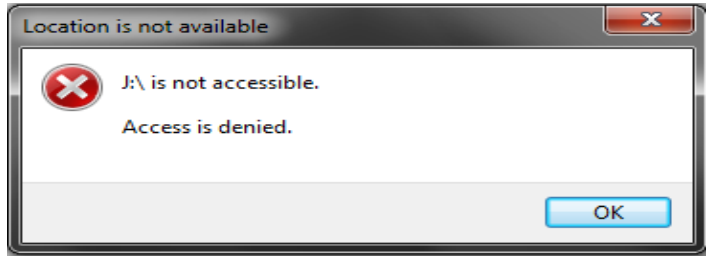

Gambar 15 Tanda Peringatan Access Ditolak

Pada Gambar 11, merupakan diagram alur pengujian. Pengujian penelitian ini dimulai ketika user menghidupkan komputer client. Setelah komputer client berhasil dihidupkan oleh user, user akanlogin to domain. Saat login to domain, secara otomatis akan menampilkan Windows Security yang berisi tentang username dan password. Pada username diisi dengan namalogon yang telah dibuat oleh administrator. Sedangkan password diisi dengan nomor induk siswa. Setelah berhasil login to domain, maka akan ditampilkan berupa Shared Folder atau Map Network Drive yang telah disharing oleh administrator. Proses selanjutnya, apakah sesuai dengan privileges yang ditentukan oleh administratorakanshared folder atau map network drive. Jika ya, user tersebut memang memiliki hak akses shared folder tersebut, maka access received (akses diterima) dan dapat mengkopi file yang ada di dalamnya. Jika user tidak memiliki hak akses folder tersebut, maka access denied (akses ditolak), sehingga user yang tidak memiliki hak akses tersebut tidak dapat mengkopi file yang ada di dalamnya. 
Pada gambar 12 merupakan login ke folder sendiri. Hal ini menjelaskan bahwa, user akanlogin ke folder yang memang menjadi hak akses foldernya.Pada gambar 13 merupakan isi folder setelah user login. Maka, akan muncul file-file yang disimpan pada folder yang telah menjadi haknya. Hal ini menjelaskan bahwa, password yang digunakan user untuk login sesuai dengan password pada Active Directory Windows Server 2008.Gambar 14 merupakan salah satu pengujian dimana user mencoba mengakses folder yang bukan haknya.

Gambar 15 adalah tanda peringatan akses ditolak. Jika seorang user akanlogin ke folder yang bukan haknya, maka akan muncul peringatan dan tidak dapat masuk pada folder tersebut. Hal ini menjelaskan bahwa password yang digunakan user untuk login tidak sesuai dengan password pada Active Directory Windows Server 2008.

\section{KESIMPULAN}

Kesimpulan yang dapat diambil dari karya ilmiah ini adalah sebagai berikut :

1. Pembangunan privileges berbasis Active Directory pada jaringan komputer di sekolah dengan menggunakan perangkat lunak sistem operasi Windows Server 2008 Enterprise pada komputer server dapat memudahkan pekerjaan administrator dalam Instalasi dan konfigurasi Active Directory dengan menggunakan sistem operasi Windows Server 2008 Enterprise yang terinstal pada komputer server SMA Negeri 2 Boyolali memudahkan administrator memanajemen user dan group serta privileges masing-masing user dan group. Para siswa, guru, dan staff karyawan dapat melihat data (file) atau mengakses file komputer server dengan cepat.

2. Manajemen user dan group penggunaan komputer bagi siswa, guru, staff karyawan dengan menggunakan Active Directory yaitu berupa membuat user dan group, mengatur hak akses. Sehingga siswa, guru, dan staff karyawan dapat mengakses atau mengkopi file melalui jaringan yang terkoneksi dengan server.

3. Dari hasil pengujian bahwa Nina, siswi kelas X dapat mengakses folder dan mengkopi file materi mata pelajaran kelas $X$ seperti : Matematika X, Fisika X, Ekonomi X, dan Geografi X, karena sesuai dengan privileges yang diberikan oleh administrator. Sedangkan hasil pada pengujian berikutnya, David siswa kelas XI IA tidak dapat mengakses folder dan mengkopi file materi mata pelajaran kelas $\mathrm{X}$, karena tidak sesuai dengan privileges yang telah ditentukan oleh administrator. Maka, akses langsung ditolak. Pengujian ini berlaku untuk user yang lainnya.

4. Hasil pertanyaan user terhadap membangun privileges berbasis Active Directory pada jaringan komputer SMA Negeri 2 Boyolali dengan Windows Server 2008 Enterprise ini sesuai dengan keinginan user dan administrator. Menurut responden, fitur kemampuan yang terdapat fitur Active Directory ini cukup membantu user terutama administrator dalam memanajemen user atau group dan menentukan hak akses (privileges) setiap user dan group. Dalam evaluasi untuk pengembangan selanjutnya, sebagian besar responden menginginkan fitur security (keamanan) dan kebijakan (policy) pada pembangunan Active Directory pada jaringan komputer SMA Negeri 2 Boyolali ini. Selain itu, ada juga sebagian yang menginginkan adanya fitur manajemen user.

\section{DAFTAR PUSTAKA}

Adin Tri Wicaksono, 2008. Membangun File Server pada Jaringan Laboratorium SMA Muhammadiyah 2 Surakarta dengan Windows Server 2008 Enterprise.Skripsi.Fakultas Komunikasi dan Informatika, Jurusan Teknik Informatika, UMS. 
Bobby Primasta, 2008. Active Directory : "Archive Active Directory Domain Services, http://wssid.org/blogs/bobbyprimasta/archive/2008/ 05/26/active-directory-domainservices.aspx, diakses tanggal 3 Juli 2013 Pukul 05.11 WIB.

Dede Supandi, 2005. Instalasi dan Konfigurasi Jaringan Komputer.Informatika.Bandung, 2005.

Elson Feza Satyagrahaprabu, 2008. Monitoring Sistem Kerja dan Pengembangan Jaringan Komputer (Networking) Rumah Sakit Moewardi Bagian Bedah Menggunakan Simulasi The Dude. Skripsi. Fakultas Teknik, Jurusan Teknik Elektro, UMS.

Joko Sulistyo, 2006. Perancangan dan Implementasi Active Directory pada Jaringan Komputer berbasis Microsoft Windows Server 2003.Skripsi. Fakultas Teknik, Jurusan Teknik Elektro, UNDIP.

Madcoms, 2005.Cepat dan Mudah Membangun Sistem Jaringan Komputer.C.V. ANDI OFFSET (Penerbit ANDI). Yogyakarta.

Melwin Syafrizal, 2005. Pengantar Jaringan Komputer hal : 2. C.V. ANDI OFFSET (Penerbit ANDI). Yogyakarta.

Modul Mata Kuliah Laboraturium Jaringan Komputer, hal : 10, 2009.

Serba-Serbi Dunia Komputer dan Internet, 2012.LDAP : "Produk yang Tersedia pada LDAP”, $\quad$ http://computermuter.blogspot.com/2012/11/ldaplightweight-directory-access.html, diakses tanggal 5 Juli 2013 Pukul 04.13 WIB.
Serba-Serbi Dunia Komputer dan Internet, 2012.LDAP : "Pengertian LDAP", http://computermuter.blogspot.com/2012/11/ldaplightweight-directory-access.html, diakses tanggal 4 Juli 2013 Pukul 20.30 WIB.

Sevidewi, 2012.LDAP : "Sejarah LDAP dan Pengertian LDAP", http://blog.ub.ac.id/sevidewi/2012/09/2 0/cara-kerja-ldap-lightweight direktory-access-protokol, diakses tanggal 4 Juli 2013 Pukul 20.12 WIB.

Squidmsdk, 2012, Active Directory : "Sejarah Active Directory", http://squidmsdk.blogspot.com/2012/10 /v-behaviorurldefaultvmlo.html, diakses tanggal 2 Juli 2013 pukul 04.07 WIB.

Supandi, Dede. 2006. Instalasi dan Konfigurasi Jaringan Komputer. Informatika.Bandung, 2006.

Windows Networking, "Quota Disk Windows Server 2008”, http://www.windowsnetworking.com, diakses tanggal 5 Juli 2013 Pukul 05.14 WIB.

Yanni Wijaya, 2012. Active Directory : "Logical and Physical Structure", http://yanniwijaya.wordpress.com/2012/0

7/active directory logical and physical structure.html, diakses tanggal 3 Juli 2013 Pukul 03.13 WIB.

Zone Networking, 2010, Active Directory: "Pengertian Active Directory", http://www.zone-

networking.co.cc/2010/01/apa-itu-activedirectory.html, diakses tanggal 2 Juli 2013 pukul 04.11 WIB. 